\title{
Pengembangan Media Pembelajaran Kimia Dasar Berbasis Web Pada Pokok Bahasan Termokimia
}

\author{
Abdul Hadjranul Fatah ${ }^{1}$, Nopriawan Berkat Asi ${ }^{1 *}$, Maya Erliza Anggraeni ${ }^{1}$, \\ Agtri Wulandari ${ }^{1}$, Abdul Latif ${ }^{1}$ \\ ${ }^{1}$ Program Studi Pendidikan Kimia, Fakultas Keguruan dan Ilmu Pendidikan, \\ Universitas Palangka Raya, Palangka Raya, Indonesia \\ *e-mail: nopriawanb@chem.upr.ac.id
}

Diterima: 4 Februari 2021; Disetujui: 3 Mei 2021; Diterbitkan: 10 Mei 2021

\begin{abstract}
ABSTRAK
Penelitian ini bertujuan untuk menghasilkan produk media pembelajaran kimia dasar berbasis web pada pokok bahasan termokimia. Penelitian ini telah dilakukan menggunakan model penelitian dan pengembangan yang meliputi tahap perencanaan (planning), desain (design), dan pengembangan (development). Data dalam penelitian ini dikumpulkan menggunakan teknik angket menggunakan kuesioner ahli media, ahli materi dan pengguna, kemudian dianalisis secara deskriptif. Hasil penelitian dan pengembangan ini menunjukkan bahwa penilaian ahli materi diperoleh rerata skor 5 (sangat baik) untuk semua aspek. Penilaian ahli media diperoleh rerata skor 5 (sangat baik) untuk semua aspek. Rerata skor hasil tes mahasiswa kelompok atas 3,9, kelompok sedang 3,6, kelompok bawah 3,2, sehingga diperoleh rerata skor 3,57 (A-) atau sangat baik. Penelitian dan pengembangan ini telah menghasilkan produk media pembelajaran kimia dasar pokok bahasan termokimia yang layak digunakan oleh mahasiswa kelompok atas, kelompok sedang dan kelompok bawah.
\end{abstract}

Kata kunci: kimia dasar, media pembelajaran, termokimia, web

\section{PENDAHULUAN}

Pandemi virus korona (covid-19) telah melanda Indonesia sejak awal tahun 2020 termasuk di Universitas Palangka Raya. Salah satu upaya yang telah dilakukan pendidik untuk melaksanakan kegiatan pembelajaran bagi peserta didik adalah memanfaatkan teknologi digital. Pemanfaatan teknologi digital memungkinkan pelaksanaan pembelajaran secara daring, karena tersedia berbagai aplikasi untuk kegiatan tatap muka secara daring seperti Zoom dan Google meet. Pendidik dilingkungan Universitas Palangka Raya memanfaatkan sistem teknologi informasi demi terwujudnya perguruan tinggi yang unggul, mandiri, kreatif, inovatif dan kompetitif. Universitas Palangka Raya terus berinovasi mengembangkan pendidikan, salah satu upaya yang diprogramkan adalah kegiatan penelitian dosen untuk meningkatkan mutu pendidikan. 
Penemuan-penemuan melalui penelitian untuk memecahkan masalah praktis berkaitan dengan penerapan pembelajaran berbasis ICT merupakan salah satu masalah mendesak dalam menghadapi era revolusi indutri 4.0, terutama khususnya pada masa pandemi virus korona. Penelitian dan pengembangan dibidang pendidikan perlu terus dikembangkan. Desain penelitian dan pengembangan adalah proses menciptakan produk atau meningkatkan hal-hal untuk memenuhi kebutuhan praktis serta menyelesaikan masalah praktis dalam pembelajaran.

Di era teknologi digital, pemanfaatan smartphone oleh mahasiswa di program studi pendidikan kimia sebagai salah satu media pembelajaran kimia perlu dipikirkan dan dikembangkan (Asi \& Anggraeni, 2018). Mata kuliah kimia dasar merupakan salah satu pelajaran yang memiliki karakteristik tersendiri dan memerlukan keterampilan khusus dalam memecahkan masalah-masalah yang berupa teori, konsep, hukum, dan fakta. Karakteristik khas pelajaran kimia tersebut berada pada tiga level reprensentasi kimia, yaitu :level makroskopik, level submikroskopik, dan level simbolik (Treagust, Chittleborough, \& Mamiala, 2003) (Chang, 2007) sehingga diperlukan visualisasi khususnya pada level submikroskopik.

Di era ini juga, proses informasi bergantung pada internet dan teknologi. Multimedia dalam pendidikan menjadi pendekatan baru dalam reformasi model pengajaran saat ini. Pembelajaran berbasis web menjadi pendekatan pembelajaran yang populer dengan perkembangan pesat teknologi web. Pembelajaran berbasis web dapat meningkatkan kinerja belajar siswa, terlebih lagi pembelajaran berbasis web memberikan siswa keterampilan komunikasi, kreativitas, keterampilan berpikir kritis dan keterampilan dalam penerapan teknologi informasi. Oleh karena itu, pendidik diharapkan mampu mengembangkan berbagai media pembelajaran memanfaatkan internet dan teknologi.

Metode Penelitian dan pengembangan dalam bahasa Inggris disebut Research and Development (R\&D), menurut Sugiyono (Sugiyono, 2012) metode penelitian dan pengembangan adalah metode penelitian yang digunakan untuk menghasilkan produk tertentu, dan menguji keektifan produk tersebut. Untuk dapat menghasilkan produk tertentu digunakan penelitian yang bersifat analisis kebutuhan (digunakan metode survei atau observasi) dan untuk menguji keefektifan produk tersebut supaya dapat berfungsi di masyarakat luas, maka diperlukan penelitian untuk menguji keefektifan produk tersebut (digunakan metode eksperimen). Produk yang dihasilkan dalam penelitian ini merupakan hasil dari analisis kebutuhan peserta didik dan digunakan untuk menguji keefektifan produk tersebut supaya dapat digunakan di masyarakat luas dan khususnya di kalangan para peserta didik program studi pendidikan kimia. Pada penelitian ini diarahkan untuk menghasilkan produk, desain, dan proses. Produk yang dihasilkan dari penelitian dan pengembangan bukan hanya berupa bahan ajar, modul, handout dan LKS, namun bisa juga dalam bentuk model, media pembelajaran e-book, audio-visual, website atau produk lainnya. 
Dalam pendidikan dan pembelajaran khususnya, penelitian pengembangan memfokuskan kajiannya pada bidang desain atau rancangan, baik berupa model, bahan ajar maupun produk seperti media pembelajaran. Borg dan Gall (Gall, Gall, \& Borg, 2003) mengemukakan bahwa "unfotunately, $R \& D$ still plays a minor role in education..." yang artinya $\mathrm{R} \& \mathrm{D}$ masih sedikit digunakan di dalam pendidikan, termasuk di Program Studi Pendidikan Kimia Universitas Palangka Raya. Pernyataan di atas bermaksud bahwasanya penelitian dan pengembangan masih sangat minim (jarang) dilakukan dalam lingkungan pendidikan kimia Universitas Palangka Raya. Banyak produk tertentu pada dunia pendidikan yang harus dikembangkan melalui metode Penelitian dan Pengembangan (R \& D). Untuk dapat menghasilkan produk tertentu digunakan penelitian yang bersifat analisis kebutuhan dan untuk menguji keefektifan produk tersebut agar dapat berfungsi di masyarakat luas maka diperlukan penelitian untuk menguji keefektifan produk tersebut. Berdasarkan definisi yang dikemukan oleh para ahli maka dapat disimpulkan bahwa penelitian dan pengembangan adalah suatu prosedur yang digunakan untuk mengembangkan produk baru atau menyempurnakan produk yang sudah ada dan menguji keefektifan produk tersebut agar dapat digunakan sesuai kebutuhan.

Uji coba model atau produk merupakan bagian yang sangat penting dalam penelitian pengembangan, yang dilakukan setelah rancangan produk selesai. Uji coba model atau produk bertujuan untuk mengetahui apakah produk yang dibuat layak digunakan atau tidak. Uji coba model atau produk juga melihat sejauh mana produk yang dibuat dapat mencapai sasaran dan tujuan. Model atau produk yang baik memenuhi 2 kriteria yaitu: kriteria pembelajaran (instructional criteria) dan kriteria penampilan (presentation criteria). Uji dilakukan 3 tahap yang meliputi: (1) Uji ahli (2) Uji coba perorangan dan kelompok kecil; (3) Uji coba lapangan (field Testing). Kualitas dan kelayakan model atau produk yang dikembangkan dapat diketahui melalui uji coba.

Penelitian ini menggunakan model pengembangan yang diadopsi dari Alessi \& Trollip dalam penelitian dan pengembangan Nazalin \& Muhtadi (Nazalin \& Muhtadi, 2016). Adapun bagan langkah-langkah penelitiannya disajikan pada Gambar 1. Ada tiga tahap yang dilakukan yaitu, merencanakan (planning), merancang (design) dan mengembangkan (development).

Website pembelajaran merupakan salah satu bentuk media pembelajaran. Media pembelajaran memanfaatkan komputer untuk membuat dan menggabungkan teks, grafik, audio, gambar bergerak (video dan animasi) dengan menggabungkan link dan tool yang memungkinkan pemakai melakukan navigasi, berinteraksi, berkreasi dan berkomunikasi. Media memiliki kemampuan untuk mengakomodasi respon peserta didik terhadap materi (Suyanto, 2003). Pembelajaran berbasis web dapat meningkatkan pengetahuan dan kemampuan berkomunikasi mahasiswa perguruan tinggi (Jiang, 2014). Produk media pembelajaran berbasis web yang dihasilkan diharapkan layak digunakan oleh mahasiswa. 


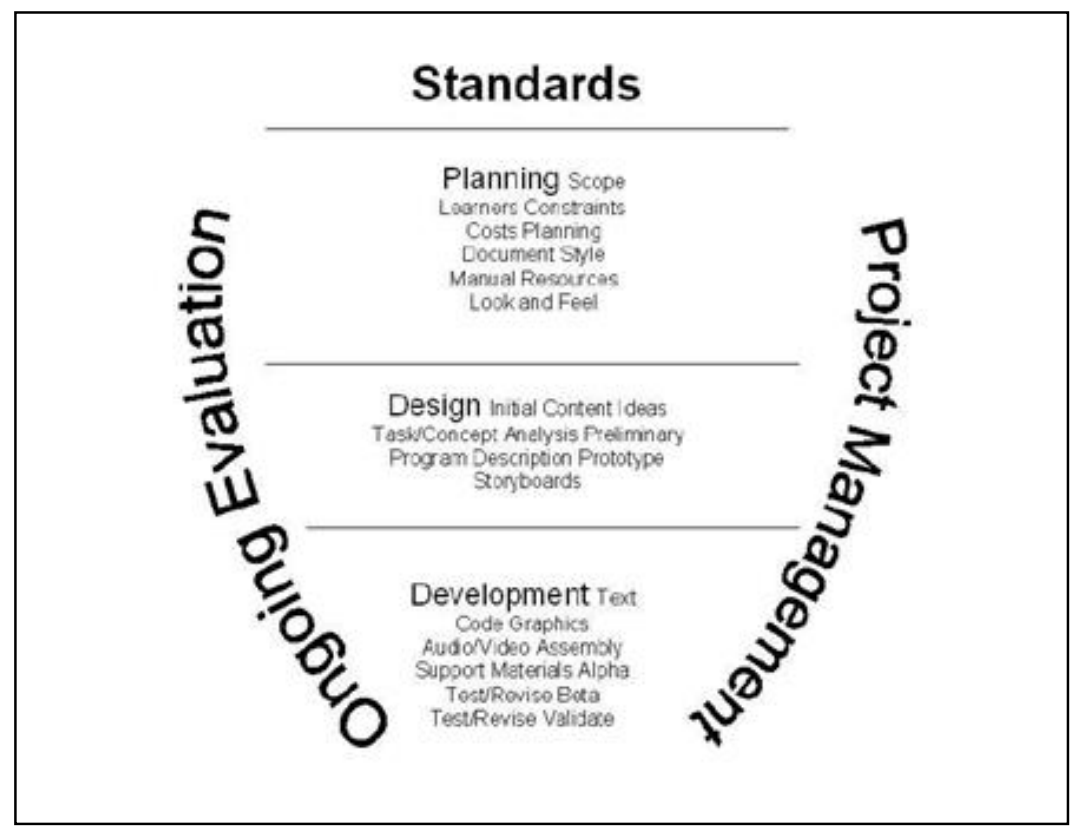

\section{Gambar 1. Bagan langkah-langkah penelitian model Alessi dan Trollip}

\section{METODE PENELITIAN}

Penelitian ini adalah jenis penelitian dan pengembangan yang dilakukan secara prosedural dan sistematis mengikuti model tertentu. Penelitian dan pengembangan dirancang untuk menghasilkan produk media pembelajaran kimia dasar berbasis web pokok bahasan termokimia. Model pengembangan yang digunakan dalam penelitian ini adalah model penelitian Research and Development $(R \& D$ mengikuti model ADDIE yang diadopsi dari Alessi dan Trolip dalam penelitian Nazalin dan Muhtadi (2016) sehingga diasumsikan model ini juga dapat digunakan untuk mengembangkan produk media pembelajaran kimia dasar berbasis web. Penelitian ini dilakukan dalam tiga tahap yaitu: perencanaan (Planning), perancangan (Design), dan pengembangan (Development). Penelitian ini dilakukan sampai menghasilkan produk akhir dan dilanjutkan sampai tahapan pengujian model secara terbatas. Dalam model $R \& D$, penelitian dilakukan sampai tahap revisi produk akhir seperti yang dilakukan oleh Nazalin dan Ali Muhtadi.

Instrumen yang digunakan berupa kuesioner yang diberikan kepada ahli materi (3 orang), ahli media (3 orang) dan pengguna (21 orang). Data yang diperoleh dalam penelitian ini dianalisis secara deskriptif.

\section{HASIL PENELITIAN DAN PEMBAHASAN}

Tahap perencanaan (planing) menentukan lingkup pengembangan media pembelajaran untuk pengguna mahasiswa program studi pendidikan kimia Universitas Palangka Raya pada mata kuliah kimia dasar 1 tahun ajaran 2020/2021. Materi yang dikembangkan pokok bahasan termokimia. Kendala yang dihadapi mahasiswa masih kesulitan dalam memahami konsep, hukum, fakta dan teori dalam pokok bahasan termokimia. Oleh karena itu, perlu dikembangkan media 
pembelajaran berbasis web untuk memberikan pemahaman kepada mahasiswa. Biaya yang diperlukan untuk mengembangkan media pembelajaran berbasis web tidaklah mahal. Layanan blogger.com memungkinkan pendidik untuk mengembangkan website secara gratis dengan syarat memiliki e-mail @gmail.com. Selain itu google juga menyediakan penyimpanan gratis dengan kapasitas 15 giga byte sehingga pengguna tidak perlu lagi menyewa domain dan membayar hosting yang memerlukan biaya ratusan ribu hingga jutaan rupiah. Google juga menyediakan drive, dan berbagai aplikasi lainnya seperti google doc, google form dan lain-lain yang dapat digunakan secara gratis. Dokumen yang dihasilkan dapat disimpan pada laman website dengan format html maupun pada drive dalam berbagai format. Sumber daya yang diperlukan adalah perangkat komputer yang terintegrasi dengan internet. Pengembang tidak harus menguasai bahasa program atau teknik coding untuk membuat web atau blog, sebab banyak fitur yang diperlukan telah disediakan blogger.com. Sumber materi diterjemahkan dari buku Chemistry edisi 10 Raymon Chang. Aplikasi atau software pendukung menggunakan Microsoft Office 2016 dan Windows Paint 2010 bukan versi premium. Semua kebutuhan yang diperlukan untuk pengembangan media pembelajaran kimia dasar berbasis web pokok bahasan termokimia telah tersedia dengan baik.

Tahap perancangan (designing) dimulai dengan mengembangkan ide muatan website pembelajaran. Konsep penting dalam termokimia dimulai dengan mempelajari jenis-jenis energi dan sifat energi, yang pada prinsipnya energi dapat diubah dari satu bentuk energi ke bentuk energi lainnya. Termokimia merupakan studi tentang perubahan energi dalam reaksi kimia. Dapat diketahui bahwa sebagian besar reaksi bersifat endotermik (menyerap kalor) dan sebagian lagi bersifat eksotermik (melepas kalor). Termokimia sebagai bagian dari subjek studi yang lebih luas yang disebut termodinamika. Hukum pertama termodinamika didasarkan pada hukum kekekalan energi. Perubahan energi dalam yang dapat diekspresikan dalam hal perubahan kalor dan kerja yang dilakukan suatu sistem. Istilah baru untuk energi, yang disebut entalpi, yang perubahannya berlaku untuk proses yang dilakukan dalam keadaan tekanan tetap. Cara untuk mengukur kalor reaksi disebut kalorimetri, perlu dimaknai istilah kalor jenis dan kapasitas kalor, kuantitas yang digunakan dalam pekerjaan eksperimental. Entalpi pembentukan standar reaktan dan produk memungkinkan untuk menghitung entalpi suatu reaksi. Cara untuk menentukan entalpi reaksi baik dengan metode langsung atau dengan metode tidak langsung, yang didasarkan pada hukum Hess. Perubahan kalor ketika zat terlarut dalam pelarut (kalor larutan) dan ketika larutan diencerkan (kalor pengenceran). Setiap reaksi kimia mematuhi dua hukum dasar: hukum kekekalan massa dan hukum kekekalan energi.

Pada tahap ini juga dilakukan analisis awal konsep/tugas (task/concept: analyses preliminary) untuk melihat rancangan awal. Setiap bagian isi dirancang dengan tampilan pada laman yang berbeda. Setiap laman diberi judul sesuai bagian 
isi. Menu navigasi dirancang menggunakan menu drop down sehingga memudahkan pengguna. Storyboards dirancang berisi tujuan pembelajaran, daftar isi, pokok bahasan dan sub pokok bahasan beserta uraiannya, contoh soal dan latihannya, ringkasan konsep-konsep, kata kunci dan soal-soal ulangan. Pada tahap ini dilakukan pemilihan tema, mendesain tata letak atau layout.

Tahap pengembangan (development) website menggunakan menu blogger.com. Alamat website atau blog yang dikembangkan adalah www.kimiadasaruniversitas.blogspot.com kemudian dialihkan menjadi alamat domain www.chem.co.id. Blog diberi judul KIMIA sesuai muatan isi. Blog didesain menggunakan menu blogger.com yang tersedia. Penggabungan teks, gambar, grafik, tabel, audio dan video yang diperlukan dibuat menggunakan menu new post (lihat Gambar 3).

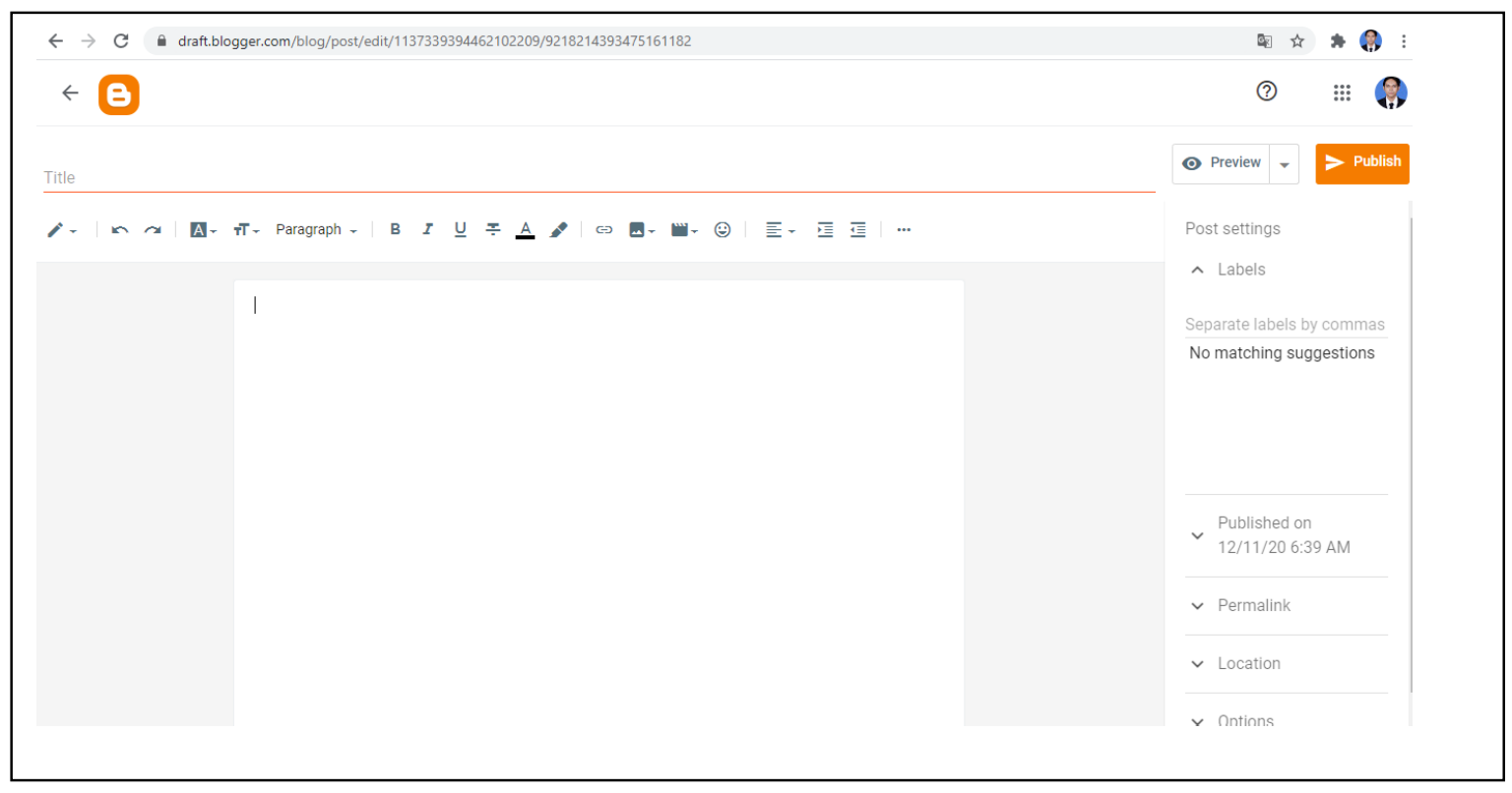

\section{Gambar 3. Menu new post}

Materi termokimia yang diterjemahkan dari buku Chemistry edisi 10 Raymond Chang terdiri dari 7 konsep termokimia, yaitu :1) sifat energi dan jenis energi, 2) perubahan energi dalam reaksi kimia, 3) hukum pertama termodinamika, 4) entalpi reaksi kimia, 5) kalorimetri, 6) entalpi reaksi dan entalpi pembentukan standar, 7) kalor pelarutan dan pengenceran. Pembahasan setiap konsep dikembangkan menggunakan menu new post (lihat Gambar 4). 


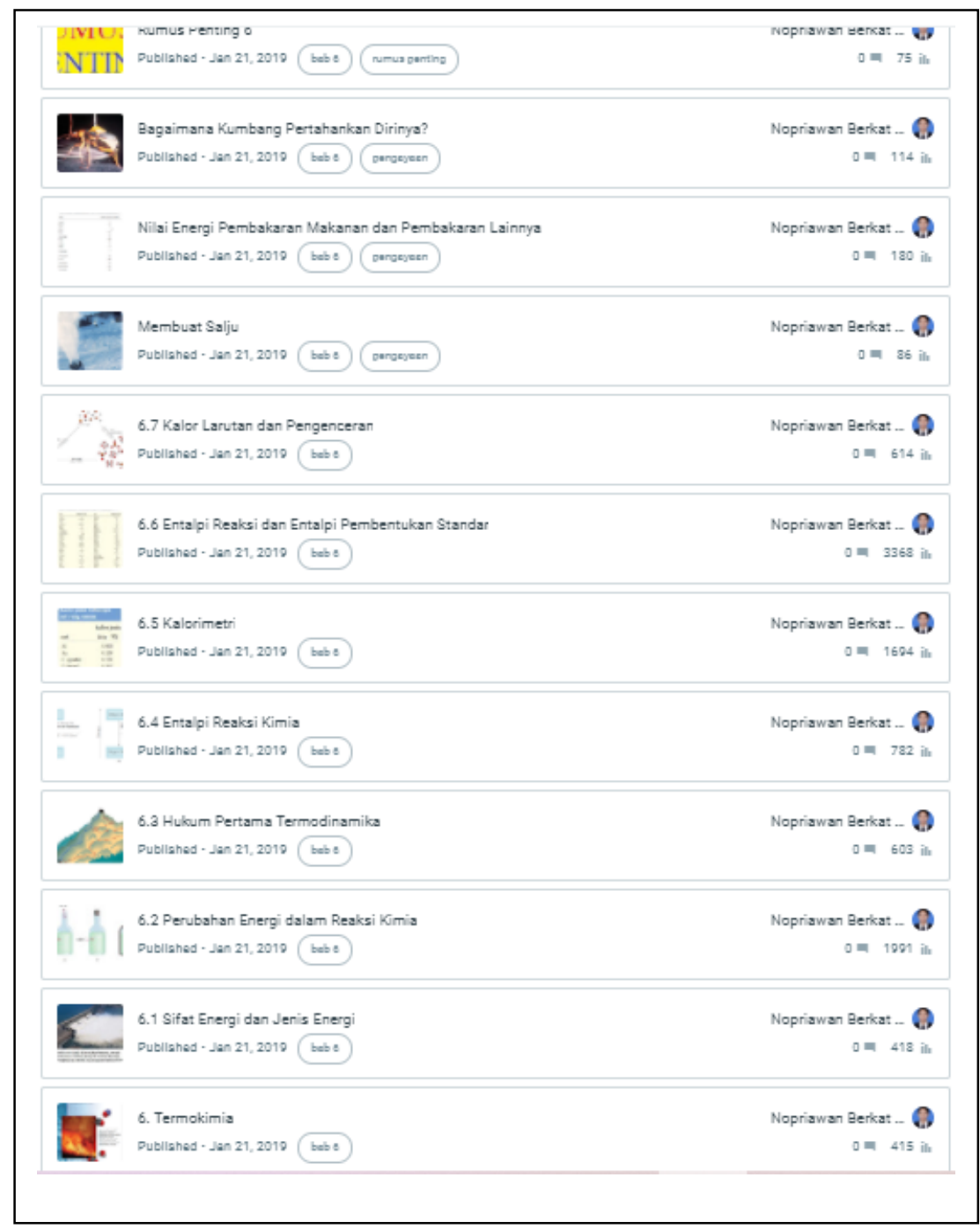

\section{Gambar 4. List hasil pengembangan materi menggunakan menu new post}

Tes alfa dilakukan oleh ahli materi untuk mengetahui kelayakan materi ajar. Validasi oleh ahli materi terdiri dari dua aspek yaitu aspek pembelajaran dan isi. Penilaian yang dilakukan oleh ahli materi pada aspek pembelajaran diperoleh rerata sebesar 5 (sangat baik). Penilaian yang dilakukan oleh ahli materi pada aspek isi materi diperoleh rerata sebesar 5 (sangat baik). Hasil penilaian yang dilakukan oleh dua orang ahli materi dilihat pada Tabel 1.

\section{Tabel 1}

Rekapitulasi penilaian ahli materi

\begin{tabular}{lccccc}
\hline \multirow{2}{*}{ Aspek Penilaian } & \multicolumn{3}{c}{ Skor Ahli Materi } & Rerata & Kategori \\
\cline { 2 - 4 } & 1 & 2 & 3 & & \\
\hline Aspek Pembelajaran & 5 & 5 & 5 & 5 & Sangat Baik \\
Aspek Isi & 5 & 5 & 5 & 5 & Sangat Baik \\
Rata-rata & 5 & 5 & 5 & 5 & Sangat Baik \\
\hline
\end{tabular}


Penilaian bahan ajar dalam bentuk web dilakukan oleh tiga orang sejawat yang menguasai tentang media pembelajaran. Penilaian media website perlu dilakukan untuk mengetahui kelayakannya menurut ahli media. Hasil penilaian ahli media diringkas dalam Tabel 2.

\section{Tabel 2}

Rekapitulasi penilaian ahli media

\begin{tabular}{lccccc}
\hline \multicolumn{1}{c}{ Aspek Penilaian } & \multicolumn{3}{c}{ Skor Ahli Media } & Rerata & Kategori \\
\cline { 2 - 4 } & 1 & 2 & 3 & & \\
\hline Rekayasa Perangkat Lunak & 5 & 5 & 5 & 5 & Sangat Baik \\
Desain Media & 5 & 5 & 5 & 5 & Sangat Baik \\
Komunikasi Visual & 5 & 5 & 5 & 5 & Sangat Baik \\
Rata-rata & 5 & 5 & 5 & 5 & Sangat Baik \\
\hline
\end{tabular}

Uji coba pengguna media pembelajaran kimia dasar berbasis web pokok bahasan termokimia dilakukan kepada mahasiswa program studi pendidikan Biologi untuk mengetahui hasil belajar mahasiswa setelah belajar menggunakan website. Mahasiswa dikelompokkan ke dalam kelas atas, kelas sedang dan kelas bawah. Kriteria layak dapat diterima jika rerata skor minimal 2,51 (B') atau cukup. Hasil tes menunjukkan bahwa pembelajaran termokimia menggunakan website efektif digunakan untuk kelas atas, kelas sedang dan kelas bawah. Ringkasan hasil belajar mahasiswa ditunjukkan pada Tabel 3.

\section{Tabel 3}

Rekapitulasi hasil tes mahasiswa

\begin{tabular}{lccc}
\hline \multicolumn{1}{c}{ Kategori Siswa } & Rerata & Kriteria & \\
\hline Kelas Atas & 3,90 & $\mathrm{~A}$ & (sangat baik sekali) \\
Kelas Sedang & 3,60 & $\mathrm{~A}^{-}$ & (sangat baik) \\
Kelas Bawah & 3,20 & $\mathrm{~B}^{+}$ & (baik) \\
Rata-rata & 3,57 & $\mathrm{~A}^{-}$ & (sangat baik) \\
\hline
\end{tabular}

Respon mahasiswa terhadap media pembelajaran kimia dasar berbasis web pokok bahasan termokimia dikumpulkan dengan teknik angket menggunakan kuesioner. Kuesioner diisi oleh 21 orang mahasiswa. Hasil kuesioner yang telah dianalisis menunjukkan bahwa 100\% mahasiswa senang belajar kimia dasar, 100\% mahasiswa tertarik belajar termokimia, 90\% mahasiswa menyatakan belajar kimia menggunakan website bukan hal baru, $100 \%$ mahasiswa menyatakan termotivasi belajar termokimia menggunakan website, 100\% mahasiswa menyatakan bahwa tulisan dan gambar yang ditampilkan pada website jelas dan mudah dipahami, $100 \%$ mahasiswa menyatakan belajar menggunakan website menarik dan menyenangkan, 90\% mahasiswa menyatakan gambar yang ditampilkan membantu 
mereka memahami konsep termokimia, 90\% mahasiswa menyatakan senang mengerjakan tugas dan latihan yang diberikan menggunakan website.

\section{SIMPULAN}

Produk hasil pengembangan adalah media pembelajaran kimia dasar berbasis web pokok bahasan termokimia dengan alamat https://www.chem.co.id. Produk yang dihasilkan layak digunakan sebagai media pembelajaran kimia dasar bagi mahasiswa. Respon mahasiswa terhadap media pembelajaran yang dihasilkan sangat baik.

\section{UCAPAN TERIMAKASIH}

Terima kasih kami ucapkan kepada unsur pimpinan Fakultas Keguruan dan Ilmu Pendidikan Universitas Palangka Raya yang telah mempercayakan dana DIPA PNBP UPR untuk mendanai penelitian ini sehingga dapat diselesaikan. Semoga produk penelitian ini bermanfaat untuk memajukan pendidikan di Universitas Palangka Raya.

\section{DAFTAR PUSTAKA}

Asi, N. B., \& Anggraeni, M. E. (2018). Pengembangan media pembelajaran kimia dasar berbasis web pokok bahasan atom, molekul dan ion. Prosiding Seminar Nasional Pendidikan Kimia (pp. 108-116). Banjar Masin: Universitas Lambung Mangkurat.

Chang, R. (2007). Chemistry 10th edition. New York: McGraw-Hill.

Gall, M. D., Gall, J. P., \& Borg, W. R. (2003). Educational reserch: an introduction 7th edition. United States of America: Pearson Education Inc.

Jiang, B. (2014). Web-based cooperative learning in college chemistry teaching. International Journal of Emerging Technologies in Learning (iJET), 45-47.

Nazalin, \& Muhtadi, A. (2016). Pengembangan multimedia interaktif pembelajaran kimia pada materi hidrokarbon untuk siswa kelas XI SMA. Jurnal Inovasi Teknologi Pendidikan Vol. 3, No. 2, 221-236.

Sugiyono. (2012). Metode penelitian pendidikan pendekatan kuantitatif, kualitatif dan $R \& D$. Bandung: Alfabeta.

Suyanto, M. (2003). Multimedia alat untuk meningkatkan keunggulan bersaing. Yogyakarta: Penerbit Andi.

Treagust, D., Chittleborough, G., \& Mamiala, T. (2003). The role of submicroscopic and symbolic representation in chemical explanations. International Journal of Science Education Vol. 25, No. 11, 1353-1368. 